\title{
PROTECTING THE PUBLIC? CHALLENGING THE INDEFINITE PREVENTATIVE DETENTION OF NON-CITIZENS
}

\author{
Chloë Marong*
}

\begin{abstract}
This paper examines the indefinite preventative detention of non-citizens in the UK, arguing that the reasoning of the House of Lords in Av Secretary of State for the Home Department has not been applied within the crime control context. This paper analyses the jurisprudence in relation to indefinite preventive detention in the (non-terrorism) immigration context, arguing that whilst ideas emerging in anti-terrorism law have influenced immigration law, in a wider context, beyond terrorism, the internal logic of immigration control which justifies its discriminatory coercion with assertion of the sovereign right of the state to exclude aliens, has caused resistance to the reasoning of the majority of the House of Lords in A in regard to the preventive detention of non-citizens. It contends that the UK's reliance on these principles is undermined by the fact that the UK has exercised its sovereignty to expressly limit it through its ratification of the European Convention on Human Rights and other international human rights instruments.
\end{abstract}

\section{A. INTRODUCTION}

"Democracy values each person equally. In most respects, this means that the will of the majority must prevail. But valuing each person equally also means that the will of the majority cannot prevail if it is inconsistent with the equal rights of minorities... No one has the right to be an international terrorist. But substitute 'black', 'disabled', 'female', 'gay', or any other similar adjective for 'foreign' before 'suspected international terrorist' and ask whether it would be justifiable to take power to lock up that group but not the 'white', 'able-bodied', 'male' or 'straight' suspected international terrorists. The answer is clear".

- Lady Hale, A v Secretary of State for the Home Department [2004] UKHL 56, paras

$237-238$

The House of Lords found that the indefinite executive detention of non-citizens was unlawful in Av Secretary of State for the Home Department ${ }^{1}$ as it was discriminatory, and

\footnotetext{
* Chloë Marong holds an LLB (Hons) and a LLM (Dist) in Human Rights Law, both from University College London. She has recently completed a LLM at Birkbeck School of Law. She has worked with NGOs assisting asylum seekers and refugees in the UK, and with international human rights NGOs.
} 


\section{Protecting the Public? Challenging the Indefinite Preventive Detention of Non- Citizens}

because its discriminatory operation rendered it unsuitable as a means of combating the risk of terrorism. Following the House of Lords judgment, the government repealed the detention regime of Part 4 of the Anti-terrorism, Crime and Security Act 2001, and enacted the Prevention of Terrorism Act 2005, which created a system of control orders, which were themselves replaced by the less restrictive Terrorism Prevention and Investigation Measures (TPIMs) by the Coalition Government. ${ }^{2}$ Yet indefinite preventive detention at the behest of the Executive is alive and well in the UK, as the reasoning of the House of Lords has not been applied in the context of immigration control. Foreign national prisoners (FNPs) are often subjected to another period of detention after their custodial sentence has been served which, because of various barriers to removal, can amount to preventive detention. Thus, non-citizens who are considered to pose a risk of crime, such as ex-foreign national prisoners, can be detained to prevent offences being committed, in circumstances where citizens could not be detained. Preventive detention for British citizens is possible in criminal law, but only if their detention is pursuant to a custodial sentence imposed by a court, such as indeterminate sentence for public protection, ${ }^{3}$ known as IPP. Furthermore, non-citizens considered to pose a risk of crime are arguably in a worse position than non-citizens suspected of involvement in international terrorism, as the latter are subjected to TPIMs instead of indefinite detention.

This article examines why the logic of the reasoning of the House of Lords regarding nationality discrimination in $A$ has been resistant to the context of preventive detention of non-citizens under immigration powers. Section B sets out the issues and Section C analyses these issues and their conceptual underpinning. This paper argues that this resistance against applying the principles in $A$ to preventive detention in the immigration context has not only led to policy effects that are indefensible in terms of risk management, but that the basis of the resistance is at best reliant on a false premise - that the preventively detained non-citizen is imprisoned within a "prison with three walls" - and at worst is unprincipled and results from the deference afforded to the Executive in the area of immigration by the doctrine of territorial state sovereignty. In any event, the current legal approach to preventive detention of non-citizens is flawed and is incompatible with fundamental principles such as equality before the law and the security of the person.

\footnotetext{
${ }^{1}$ [2004] UKHL 56 (HL); [2005] HRLR 1.

2 s23 of the Anti-Terrorism, Crime and Security Act 2001 was repealed by s 16(2)(a) Prevention of Terrorism Act 2005, which was itself repealed by s 1 Terrorism Prevention and Investigation Measures Act 2011 which replaced the control orders regime with less restrictive Terrorism Prevention and Investigation Measures (TPIMs) sometimes referred to as "control orders-lite"; see for example Alan Travis, "Control orders: home secretary tables watered-down regime', Guardian 26 January 2011.

${ }^{3}$ s 225 Criminal Justice Act 2003 as amended by s 13(1) Criminal Justice and Immigration Act 2008 s 13(1).
} 


\section{B. THE ISSUES}

\section{Not Conducive to the Public Good}

a) Statutory powers of detention

The Immigration Act $1971^{4}$ confers a wide power on immigration officers to detain various categories of persons, pending their examination or their removal from the UK, and corresponding powers are conferred on the Secretary of State by the Nationality, Immigration and Asylum Act 2002. ${ }^{5}$ Where a court makes a recommendation for deportation against a person who is not detained under order or sentence of a court, paragraph 1 of Schedule 3 to the 1971 Act provides for automatic detention, unless the court making the recommendation, or the Secretary of State, directs otherwise, or he or she is released on bail. Similarly, under paragraph 2 of Schedule 3 a person who has been given notice of a decision to make a deportation order can be detained pending the making of the order and, under paragraph 3 of Schedule 3, once the order is in force will continue to be detained unless released on bail or the Secretary of State directs otherwise. The power to detain is therefore a corollary to the power to deport. A person who is not a British citizen is liable to be deported, under Section 3(5)(a) of the Immigration Act $1971^{6}$ if the Secretary of State "deems his deportation to be conducive to the public good."

Following a media furore in April 2006, when it emerged that 1,023 FNPs had been released without being considered for deportation, Section 32 of the UK Borders Act 2007 introduced automatic deportation for FNPs who had been sentenced to twelve months imprisonment or more. This automatic deportation is subject to various exceptions under Section 33, which enable the person to challenge their deportation. Section 36 of the UK Borders Act 2007 also allows the Secretary of State to detain a person whilst the Secretary of State considers whether the automatic detention provision applies, and where they have decided that it does apply, pending the making of the deportation order.

\section{b) Policy}

The Drugs Offences (Bournemouth Commitment) ${ }^{7}$ policy, implemented following a verbal commitment made at the September 2007 Labour Party conference by the then Prime Minister, provides that all non-EEA nationals involved in gun crime or a serious drug offence

\footnotetext{
${ }^{4}$ Schedule 2, Paragraph 16.

5 s62.

${ }^{6}$ As substituted by s 169(1) of and para 44(2) of Schedule 14 to the Immigration and Asylum Act 1999.

${ }^{7}$ Drugs Offences (Bournemouth Commitment) vers 6.0 Valid from 19 November 2013

<http://www.ukba.homeoffice.gov.uk/sitecontent/documents/policyandlaw/modernised/criminality-anddetention/drug-offences-bournemouth-comm?view=Binary> accessed 30 May 2014.
} 


\section{Protecting the Public? Challenging the Indefinite Preventive Detention of Non- Citizens}

will be considered for removal from the UK regardless of the length of the sentence. There is a tension at the heart of the use of detention powers, with the requirements of human rights standards and of political expediency sometimes pulling in opposite directions. The UN High Commissioner for Refugees has urged that "[t]here should be a presumption against detention", and the Human Rights Committee has found that "in order to avoid a characterization of arbitrariness, detention should not continue beyond the period for which the State party can provide appropriate justification."

The stated policy of the Home Office has consistently been that there is a presumption in favour of liberty 9 and that detention must be, and is, "used sparingly and for the shortest period necessary." ${ }^{10}$ However, there have been successive moves to expand the immigration detention estate, ${ }^{11}$ which has increased from a capacity of 250 places in $1993^{12}$ to a current capacity of $3,400,{ }^{13}$ with an unknown number of immigration detainees being held in prisons. Amnesty International has found immigration detention in the UK to be arbitrary because decisions to detain are taken on the basis, inter alia, of whether a bed is available, ${ }^{14}$ a decision making process which they call a "bed lottery." 15 The use of immigration detention powers has escalated considerably: there were 95 people detained under immigration powers in $1973,{ }^{16}$ rising to 10,240 in $1995^{17}$, and today around 30,000 people enter detention under immigration powers every year. ${ }^{18}$ In his report on his visit to the UK in 2004, the then

\footnotetext{
${ }^{8}$ C v Australia, Merits, UN Doc CCPR/C/76/D/900/1999; (2002) 10 IHRR 364, 28 October 2002, para. 8.2; Av Australia, Merits, UN Doc CCPR/C/59/D/560/1993; (1997) 5 IHRR 783 April 1997, para. 9.4.

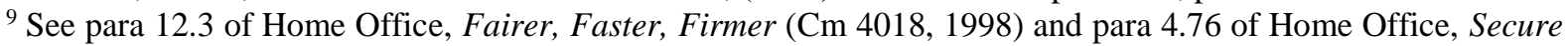
Borders, Safe Haven, the Enforcement Instructions and Guidance (Cm 5387, 2002) confirming, at 55.1.1 that the latter paper represents current policy on the use of detention.

${ }^{10}$ Government Response to the House of Lords European Union Committee Report on Illegal Migrants: Proposal for a Common EU Returns Policy,

<http://www.parliament.uk/documents/upload/060804govresrretsrp.pdf> accessed 30 May 2014, para13.

${ }^{11}$ Fairer, Faster, Firmer (n 9), para 12.14 indicated that the Government was "considering the need for an increase in the detention estate to facilitate an effective immigration control and the removal of those with no authority to remain in the UK." Secure Borders, Safe Haven (n 9), para 4.75 stated that "We have decided to increase detention capacity by a further $40 \%$, to 4,000 places in order to facilitate an increased rate of removals of failed asylum seekers and others with no basis of stay in the UK."

${ }^{12}$ Christine Bacon, 'The Evolution of Immigration Detention in the UK: The Involvement of Private Prison Companies' (2005), University of Oxford Refugee Studies Centre Working Paper No 27.

${ }^{13}$ Stephanie J Silverman and Ruchi Hajela Briefing - Immigration Detention in the UK, Migration Observatory at the University of Oxford 29 November 2013, 3 and Bail for Immigration Detainees, 'Long term immigration detention: an expensive denial of rights and liberty Bail for Immigration Detainees', Briefing Paper, July 2010, 3.

${ }^{14}$ Amnesty International, 'Seeking Asylum is not a Crime - detention of people who have sought asylum', EUR 45/015/2005, 19 June 2005, 48.

15 ibid 49.

${ }^{16}$ Mari Malmberg, 'Control and Deterrence, Discourses of Detention of Asylum-Seekers' (2004) Sussex Migration Working Paper no 20, 8.

17 ibid.

${ }^{18}$ A (n 1) 2.
} 
Council of Europe Commissioner for Human Rights, Alvaro Gil-Robles, expressed concerns about the extent of the use of immigration detention, ${ }^{19}$ and commented that "there is pressure on the immigration service to fill the increasing immigration detention estate. ${ }^{20}$ In $R$. (on the application of WL (Congo)) v Secretary of State for the Home Department ${ }^{21}$ it was found that between April 2006 and 9 September 2008 the Secretary of State had applied an unpublished policy to the detention of FNPs who had completed their prison sentences, under which there was a "near blanket ban"22 on their release, in direct contradiction of the published policy which stated that there was a presumption in favour of release. There are no statutory criteria for the authorisation of the use of immigration detention, with each set of statutory powers providing the authority to detain or release. Thomas Hammarberg, former Commissioner for Human Rights at the Council of Europe, has commented that "one problematic aspect of [administrative detention of migrants] is the high degree of discretion and broad powers of the immigration officers." 23

Administrative guidelines regarding the decision to detain or release are set out in Chapter 55 of the UK Visas and Immigration (UKVI) Enforcement Instructions and Guidance. ${ }^{24}$ At paragraph 55.3A it states:

"As has been set out above, public protection is a key consideration underpinning our detention policy. Where an ex-foreign national prisoner meets the criteria for consideration of deportation, the presumption in favour of temporary admission or temporary release may well be outweighed by the risk to the public of harm from reoffending or the risk of absconding, evidenced by a past history of lack of respect for the law."

In paragraph 55.3.1 whether "there a risk of offending or harm to the public" is listed as a relevant consideration when considering whether or not to detain, and paragraph 55.3.1 strongly emphasises that "substantial weight" should be given to the risk of further offending and the risk of harm to the public.

\footnotetext{
${ }^{19}$ Commissioner for Human Rights, Report by Mr Alvaro Gil-Robles, Commissioner For Human Rights, on His Visit to the United Kingdom 4th -12th November 2004, CommDH (2005) 6, para 42.

${ }^{20}$ ibid para 45.

${ }^{21} R$ (on the application of WL (Congo)) v Secretary of State for the Home Department [2011] UKSC 12 (SC); [2011] 2 WLR 671.

22 ibid, para. 5.

${ }^{23}$ Commissioner for Human Rights, Memorandum by Thomas Hammarberg Commissioner for Human Rights of the Council of Europe Following his visits to the United Kingdom on 5-8 February and 31 March-2 April 2008, Issues reviewed: Asylum and immigration, CommDH (2008) 23, para 51.

${ }^{24}$ UK Visas and Immigration (UKVI) Enforcement Instructions and Guidance.chs 46-62

<http://www.ukba.homeoffice.gov.uk/sitecontent/documents/policyandlaw/enforcement/detentionandremovals/ $>$ accessed 30 May 2014.
} 
According to the Association of Visitors to Immigration Detainees (AVID), many of the minor crimes committed by FNPs are immigration offences. AVID states that "[t]here are approximately 50 immigration act offences (as opposed to offences under the criminal justice system) and in 2007900 people were charged and convicted of these. ${ }^{.25}$ In this context, it is perhaps significant that the Enforcement Instructions and Guidance states "risk of offending or harm to the public" ${ }^{26}$ as alternatives, as it is clear that the first risk may not entail the second risk but may nevertheless lead to a decision to detain on preventive grounds.

\section{Indefinite Detention as an Adjunct to Immigration Control}

a) The problem

Immigration detention in the UK is indefinite. The UK has opted out of the Returns Directive which limits the length of immigration detention to six months, ${ }^{27}$ to be extended by a further twelve months if "regardless of all their reasonable efforts" 28 the removal is likely to last longer because the detainee is not cooperating with the removal, or there are delays in obtaining documentation from third countries. The UK has not introduced any legislation creating a maximum time limit for immigration detention as recommended by Hammarberg, ${ }^{29}$ to the contrary, the Home Office has made clear that it intends to increase its use of immigration detention. ${ }^{30}$ There are a number of barriers to removal of detainees that may arise and, in some cases, it may be impossible to carry out removal; thereby immigration detention pending removal can become a form of preventive detention where there is no practical possibility of removal within a reasonable period of time but where the detainee is deemed to be at risk of offending and/or causing harm to the public.

There is no automatic review by a court of decisions to detain, but the detainee can apply for bail. Section 30(2)(b) of the Immigration Act 1971 provides that the Asylum and Immigration Tribunal hearing the bail application is not obliged to release the applicant on

\footnotetext{
25 Post Sentence Foreign National Prisoners, November 2008 (notes from a workshop) $<$ http://www.aviddetention.org.uk/index.php?option=com_content\&view=article\&id=93:postsentenceforeignnat ionalprisoners\&catid=14:postsentenceforeignnationalprisoners\&Itemid=16>, accessed 30 May 2014.

${ }^{26}$ Post Sentence Foreign National Prisoners (n 25) para 55.3.1 (emphasis added).

${ }^{27}$ Council Directive 2008/115/EC of 16 December 2008 on common standards and procedures in Member States for returning illegally staying third-country nationals [2008] OJ L348/98, article 15(5).

28 ibid, article 15 (6).

${ }^{29}$ Thomas Hammarberg, Memorandum by Thomas Hammarberg Commissioner for Human Rights of the Council of Europe Following his visits to the United Kingdom on 5-8 February and 31 March-2 April 2008, Issues reviewed: Asylum and immigration.

${ }^{30}$ Mark Harper, Minister for Immigration (as he then was), HC Deb 10 June 2013, vol 564, col 16.
} 
bail if he or she is likely to commit an offence unless kept in detention. The charity Bail for Immigration Detainees has found that in cases

"where the Home Office has indicated its intention to deport a foreign national exprisoner, there is an expectation that the individual will be transferred to immigration detention at the end of their custodial sentence, and as a result foreign national prisoners are frequently not prioritised for a risk assessment as part of a pre-release plan. Post sentence detainees therefore frequently do not have access to documents that could otherwise help them argue their eligibility for bail in front of an immigration judge." 31

Part III of the Immigration and Asylum Act 1999 provided for automatic bail hearings and a presumption of the right to bail, but these provisions were never brought into force and were repealed by the Nationality, Immigration and Asylum Act 2002. Without these safeguards in place, and with increasing restrictions on legal aid, in practice immigration detention can become arbitrary detention.

Van Kalmthout argues that "[n]o automatic right to free legal advice or representation...is likely to be a factor in the low level of bail applications." 32 Gil-Robles observed that many of the detainees that he met at Dungavel and Heathrow were unaware of the reasons for their detention or the possibility of contesting it, ${ }^{33}$ and expressed concerns that " $[\mathrm{t}]$ he reasons provided to detainees by the immigration officer at the time of the decision are at best cursory and the explanation of bail rights technical and perfunctory. From my own experience in Dungavel, it was clear that those who did not have decent legal representation, of which there appeared to be plenty, had very little idea, if any at all, as to how they might begin to apply for bail." ${ }^{34}$

He also commented that restrictions on legal aid and the remote locations of many immigration removal centres made access to quality legal advice and representation "somewhat problematic." ${ }^{35}$ Similar concerns regarding detainees' access to legal advice and representation and information on their cases were expressed by Hammarberg, following his visits to the UK in 2008. Hammarberg recommended that

"the United Kingdom authorities [...] adopt measures in order to ensure that asylum and immigration detainees are kept systematically informed and are provided with on-

\footnotetext{
31 'Long term immigration detention: an expensive denial of rights and liberty' (n 13), 5.

${ }^{32}$ A.M. van Kalmthout, F.B.A.M. Hofstee-van der Meulen and F. Dünkel (Eds), Foreigners in European Prisons, vol. 2 (Wolf Legal Publishers 2007) 842.

${ }^{33}$ Report (n 19) para 43.

34 ibid para 47.

35 ibid.
} 
site, expert legal advice, so that existing alternatives to detention, such as release on bail, may easily be applied for by detainees." 36

The UN Working Group on Arbitrary Detention has highlighted the problem of indefinite detention, observing that

"some national laws do not provide for detention to be ordered by a judge, or for judicial review of the detention order. Detainees often do not enjoy the right to challenge the legality of their detention. There is no maximum length of detention established by law, which leads to prolonged or, in the worst case, potentially indefinite detention in cases, for example, where the expulsion of a migrant cannot be carried out for legal or practical reasons." ${ }^{, 37}$

The "legal or practical reasons" referred to by the Working Group on Arbitrary Detention are various, but can include de facto or de jure statelessness and difficulties in obtaining travel documents, legal prohibition of expulsion due to non-refoulement requirements, interim measures indicated by the European Court of Human Rights (ECtHR), and a lack of transportation available to the country to which the detainee would be returned. ${ }^{38}$ In March 2013, the government created a new statelessness determination procedure, but excluded advice and representation on statelessness from the scope of legal aid. To obtain leave to remain under the statelessness determination procedure, applicants must show that they are de jure stateless, and that they are not admissible to the country of their former residence or any other country. De facto stateless persons in the UK are particularly vulnerable to indefinite administrative detention - unable to obtain travel documents and unable to establish their stateless status they can be deemed to be not cooperating with the removal process.

Chapter 55 of the UK Visas and Immigration (UKVI) Enforcement Instructions and Guidance does provide that release of a FNP who has completed their sentence can be considered in cases where removal is not imminent, although "where the FNP is frustrating removal by not co-operating with the documentation process, and where that is a significant barrier to removal, these are factors weighing strongly against release." 39 The idea that detention is caused by the detainee and is therefore justifiable underpins much of the

\footnotetext{
${ }^{36}$ Memorandum (n 23), para 53.

${ }^{37}$ UN Human Rights Council, Report of the Working Group on Arbitrary Detention, A/HRC/13/30, 15 January 2010, para 62.

${ }^{38}$ The Equal Rights Trust has discovered that UKBA (as it then was) considers these problems only as barriers to removal, and not as a basis for granting leave to enter or leave to remain, see Equal Rights Trust, Unravelling Anomaly - Detention, Discrimination and the protection needs of Stateless Persons, July 2010, 115.

${ }^{39}$ UKVI Enforcement Instructions and Guidance (n 24) 55.3.2.4.
} 
jurisprudence which establishes that indefinite immigration detention is lawful under domestic and international law.

i) Immigration detention and the second class right to liberty of the non-citizen In the case of $R v$ Governor of Durham Prisons, ex parte Hardial Singh ${ }^{40}$ Woolf LJ established the principles governing immigration detention, which were summarised in $R$ (on the application of I) $v$ Secretary of State for the Home Department: ${ }^{41}$

a. The Secretary of State must intend to deport the person and can only use the power to detain for that purpose;

b. The deportee may only be detained for a period that is reasonable in all the circumstances;

c. If, before the expiry of the reasonable period, it becomes apparent that the Secretary of State will not be able to effect deportation within that reasonable period, he should not seek to exercise the power of detention;

d. The Secretary of State should act with the reasonable diligence and expedition to effect removal.

What constitutes a reasonable period was considered by the Court of Appeal in $R$ (on the application of I) $v$ Secretary of State for the Home Department,${ }^{42} R$ (on the application of A) $v$ Secretary of State for the Home Department ${ }^{43}$ and $R$ (on the application of $M$ ) $v$ Secretary of State for the Home Department. ${ }^{44}$ The Court of Appeal were in agreement in $R$ (on the application of I) $v$ Secretary of State for the Home Department that in arguing that the length of his detention was unreasonable the appellant could not rely on any delay caused by his ongoing asylum application, and furthermore that refusal to accept voluntary repatriation, and a risk of reoffending, were valid considerations. Brown LJ accepted in principle that a risk of reoffending could justify detention for an indeterminate period, ${ }^{45}$ having found in favour of the Secretary of State on the issue of whether the risk of re-offending was relevant

\footnotetext{
${ }^{40} R v$ Governor of Durham Prisons, ex p Hardial Singh [1984] 1 WLR 704 (QBD).

${ }^{41} R$ (on the application of I) $v$ Secretary of State for the Home Department [2002] EWCA Civ 888 (CA) para 46.

42 ibid, para 46.

${ }^{43} R$ (on the application of A) $v$ Secretary of State for the Home Department [2007] EWCA Civ 804 (CA).

${ }^{44} R$ (on the application of M) $v$ Secretary of State for the Home Department [2008] EWCA Civ 307(CA).

${ }^{45} R(I)(\mathrm{n} 41)$ para 37.
} 


\section{Protecting the Public? Challenging the Indefinite Preventive Detention of Non- Citizens}

to the question of whether removal would be possible within a reasonable period of time, holding that:

"[i]f, say, one could predict with a high degree of certainty that, upon release, the detainee would commit murder or mayhem, that to my mind would justify allowing the Secretary of State a substantially longer period of time within which to arrange the detainee's removal abroad." 46

In $R$ (on the application of $A$ ) $v$ Secretary of State for the Home Department the Court of Appeal found the detention of a Somali FNP for nearly three years to be lawful. The appellant had not been deported because he did not have any travel documents, and there were no airlines willing to accept passengers being forcibly returned to Somalia. In addition, the ECtHR had indicated that he should not be deported pending a decision in another case, and he also had an outstanding domestic appeal against the Secretary of State's refusal to revoke the deportation order. Despite these factors, Toulson and Keene LJJ gave particular weight to the fact that the appellant had refused to accept voluntary repatriation, whilst the reasons for his refusal were deemed to be irrelevant. ${ }^{47}$ Protecting the public from the risk of reoffending was also held to be a relevant consideration, in the words of Toulson LJ:

"Mr Drabble submitted that the purpose of the power of detention was not for the protection of public safety. In my view that is over-simplistic. The purpose of the power of deportation is to remove a person who is not entitled to be in the United Kingdom and whose continued presence would not be conducive to the public good. If the reason why his presence would not be conducive to the public good is because of a propensity to commit serious offences, protection of the public from that risk is the purpose of the deportation order and must be a relevant consideration when determining the reasonableness of detaining him pending his removal or departure." 48 In $R$ (on the application of $M$ ) $v$ Secretary of State for the Home Department Dyson $\mathrm{LJ}$ held that the detention of the appellant for fifteen and a half months was reasonable in the circumstances because of the risk of absconding and reoffending, notwithstanding the fact that there was "no immediate prospect that the deportation will take place". ${ }^{49}$ Dyson LJ found that:

\footnotetext{
${ }^{46} R(I)(\mathrm{n} 41)$ para 29.

${ }^{47} R(A)(\mathrm{n} 43)$ paras 54,57 and 79.

48 ibid para 55.

${ }^{49} R(M)(\mathrm{n} 44)$ para 37.
} 
"[T]he combination of a risk of absconding and a risk of re-offending may justify allowing the Secretary of State, in the words of Simon Brown LJ in $R(I)$ at para 29, "a substantially longer period of time within which to arrange the detainee's removal abroad." The greater the risks, the longer the period for which detention may be reasonable. But there must come a time when, whatever the magnitude of the risks, the period of detention can no longer be said to be reasonable." 50

The Supreme Court held in $R$ (on the application of WL (Congo)) $v$ Secretary of State for the Home Department ${ }^{51}$ that delays caused by an applicant's appeals could only be excluded from the period of immigration detention for the purposes of determining whether the length of detention is reasonable if the appeal is unmeritorious. However, it was confirmed that the risk of reoffending is relevant to the question of whether the period of detention is reasonable. ${ }^{52}$ Lord Dyson linked the risk of offending to detention's supposed purpose - facilitating deportation - arguing that if the detainee was to be released and reoffend, this may cause him or her to abscond, or to be convicted and sentenced, and concluding that "[e]ither way, his re-offending will impede his deportation." ${ }^{53}$ In his dissenting judgment, Lord Phillips found that the lawfulness of detention of a deportee would not be confined to circumstances where the purpose is to facilitate deportation, observing that facilitating deportation "is often the, or one of the, reasons for doing so." Counsel for the appellants had argued that the risk of offending could not be the sole justification for detention, as the purpose of detention was to facilitate deportation, not to prevent offending. Lord Phillips examined the issue of why detention was permitted to prevent offending, provided that it had been originally authorised to facilitate deportation, commenting that:

"[i]f the risk of re-offending can be the determinant factor in deciding how long it is reasonable to detain a FNP why should it not be the determinant, or even the sole reason for detaining him in the first place? Why should it be a pre-condition to the power to detain that its use is to facilitate deportation, even if this is not the real reason for detention, as in the case of Chahal? It is that logical inconsistency that underlies the challenge that is made on behalf of Mr Lumba in the present case to the legitimacy of having regard to the risk of his re-offending."

\footnotetext{
50 ibid para 14.

${ }^{51} R$. (WL (Congo)) (n 21).

52 ibid paras 108-110.

53 ibid para 109.

${ }^{54}$ ibid, para 282.
} 


\section{Protecting the Public? Challenging the Indefinite Preventive Detention of Non- Citizens}

As it is made in passing, and in the context of years of jurisprudence which has allowed an extraordinary latitude to the Executive in exercise of its immigration detention powers, finding lengthy periods of detention to be reasonable and lawful, the admission that the real reason for detention in Chahal ${ }^{55}$ was actually public protection - deportation within a reasonable period of time never being a real and practical possibility - is easily missed, but is nonetheless a startling statement.

Chahal $v U K$ is remembered for establishing the absolute nature of the principle of non-refoulement in Article 3 cases concerning deportation to a country where the applicant faces a risk of torture. Following Chahal, states are prohibited from weighing national security considerations against the individual's Article 3 right to be free from torture. However, in Chahal the ECtHR held that the applicant's detention for a period of over five years following the making of a deportation order against him was lawful and the length of detention was not excessive in breach of Article 5(1)(f), as the Secretary of State had acted with due diligence in pursuing deportation proceedings. The prolonged period was lawful because of its link to deportation, yet Lord Phillips casts that purpose aside, considering the detention to be, in reality, preventive detention.

The absolute nature of the prohibition of deportation to a country where there is a risk that the deportee will suffer torture has led to the UK using preventive detention as an alternative to breaching its non-refoulement obligations under Article 3 of the European Convention on Human Rights (ECHR). The irony of this is not lost on the Equal Rights Trust, which, in its report "Unravelling Anomaly - Detention, Discrimination and the protection needs of Stateless Persons" 56 comments:"[h]owever, the problem often faced by stateless persons is that even though they may benefit from the principle of non-refoulement, the alternative they are often afforded is one which also violates their rights - continued detention" 57 The Equal Rights Trust argues that indefinite detention is a form of inhuman and degrading treatment in itself and therefore

"it is obvious that resorting to indefinite detention in order to protect a person from possible torture, cruel, inhuman or degrading treatment in another country is absurd.

If the motivation to not refoul persons is based on a commitment to protect them from

\footnotetext{
${ }^{55} R$ v Secretary of State for the Home Department [1995] 1 WLR 526 (CA) and Chahal v United Kingdom (1996) 23 EHRR 413 (ECtHR).

${ }^{56}$ Equal Rights Trust, Unravelling Anomaly - Detention, Discrimination and the protection needs of Stateless Persons (2010)

$<$ http://www.equalrightstrust.org/ertdocumentbank/UNRAVELLING\%20ANOMALY\%20small\%20file.pdf>ac cessed 30 May 2014.

57 ibid, 68 .
} 
torture, cruel, inhuman and degrading treatment, the consequences of actions under such a commitment must not result in a violation of the same right."

Lord Phillip's judgment in WL relied largely on an expansive conception of territorial sovereignty. In his analysis of the detention powers under the Immigration Act 1971, Lord Phillips took as his starting point the contention that " $[\mathrm{t}]$ he Secretary of State is not required to permit an immigrant who has unlawfully entered this country to roam free." 58 Irregular migrants, including many asylum seekers, therefore do not have the same rights to liberty and security of the person as people lawfully resident in the UK. Although the exercise of the statutory power to detain is subject to the constraints of public law principles, Lord Phillips held that the principle of rationality does not preclude public protection being a purpose of immigration detention; "[i]t is rational and lawful to detain a FNP pending deportation to prevent his re-offending or because he would pose a security risk if at large, just as it is rational and lawful to detain him because of the risk of his absconding."59

The jurisprudence of the UK courts and the ECtHR confirms that the foundational principle of the statutory immigration powers is territorial sovereignty, and that this provides wide discretion for the Secretary of State to detain aliens. The right to exclude from its territory, and to control admission to and residence in its territory, is fundamental to the modern nation state, and appears to create a partial shield against judicial scrutiny, under which a lower standard of review is applied in cases involving territorial sovereignty. The state's "undeniable sovereign right to control aliens' entry into and residence in their territory" ${ }^{60}$ appears predominantly to trump the rights of the detained alien throughout the case law, at both domestic and international levels.

Article 5(1) of the ECHR provides that "[e]veryone has the right to liberty and security of person. No one shall be deprived of his liberty save in the following cases and in accordance with a procedure prescribed by law." It then enumerates an exhaustive list of five cases in which deprivation of liberty is justified, including, at 5(1)(f), "the lawful arrest or detention of a person to prevent his effecting an unauthorised entry into the country or of a person against whom action is being taken with a view to deportation or extradition." The ECtHR has taken a very deferential approach in its case law on Article 5(1)(f), finding detention to be lawful as long as deportation proceedings are handled with due diligence, ${ }^{61}$

\footnotetext{
${ }^{58} R$. (WL (Congo)) (n 21) para 283.

59 ibid, para 284.

${ }^{60}$ Saadi v United Kingdom (2008) 47 EHRR 17 (ECtHR), para 64.

${ }^{61}$ Chahal $v$ United Kingdom (1997) 23 EHRR 413, para 123. The applicant's detention for six years was found to be lawful under article 5(1)(f), in contrast to the Commission's finding that proceedings were "not pursued
} 


\section{Protecting the Public? Challenging the Indefinite Preventive Detention of Non- Citizens}

allowing unnecessary detention, and explicitly applying a limited version of the doctrine of proportionality, holding that "the principle of proportionality applied to detention under Art.5(1)(f) only to the extent that the detention should not continue for an unreasonable length of time" with unreasonableness being determined by the Chahal due diligence test.

The ECtHR's approach to Article 5(1)(f) is in marked contrast to its jurisprudence on Article 5(1)(e), the sub-paragraph that provides for "the lawful detention of persons for the prevention of the spreading of infectious diseases, of persons of un-sound mind, alcoholics or drug addicts or vagrants." Both sub-paragraphs do not stipulate that detention should be necessary, but the ECtHR held in Winterwerp $v$ Netherlands ${ }^{62}$ and Litwa $v$ Poland $^{63}$ that where persons of unsound mind or alcoholics are detained unnecessarily such detention may be unlawful. In Litwa the ECtHR found that "[t]he detention of an individual is such a serious measure that it is only justified where other, less severe measures have been considered and found to be insufficient to safeguard the individual or public interest which might require that the person concerned be detained." 64 The dissenting opinions in Saadi strongly criticised the resulting two-tiered protection of Article 5:

"[u]ltimately, are we now also to accept that Art.5 of the Convention, which has played a major role in ensuring controls of arbitrary detention, should afford a lower level of protection as regards asylum and immigration which, in social and human terms, are the most crucial issues facing us in the years to come? Is it a crime to be a foreigner? We do not think so". ${ }^{65}$

ii) The Prison with three walls

A detainee's refusal to return voluntarily to his or her country of origin is used to construct an argument refuting the discriminatory nature of the preventive detention of non-citizens in circumstances where UK citizens would not be detained. According to this argument, which takes a formal approach to equality, ${ }^{66}$ the detention regime is not discriminatory because the

\footnotetext{
with the requisite speed" (para 120) the Court found that the deportation proceedings had been pursued with due diligence and therefore the detention was lawful.

${ }^{62}$ Winterwerp v Netherlands (1979-80) 2 EHRR 387 (ECtHR), para 37.

${ }^{63}$ Litwa v Poland (2001) 33 EHRR 53 (ECtHR), para 78.

${ }^{64}$ ibid.

${ }^{65}$ Saadi v United Kingdom (n 60), Joint Partly Dissenting Opinion of Judges Rozakis, Tulkens, Kovler, Hajiyev, Spielmann and Hirvelä, para O-I19.

${ }^{66}$ For discussion of different approaches to equality, for example, Sandra Fredman, Discrimination Law, (OUP 2002), ch 1; Christopher McCrudden, 'The New Concept of Equality' (Trier, 2-3 June 2003, ERA Congress Centre)<http://www.era-comm.eu/oldoku/Adiskri/02_Key_concepts/2003_McCrudden_EN.pdf> accessed 30 May 2014.
} 
relevant comparator is not a British national who poses a risk of offending or causing harm to the public, because he or she could not be deported and therefore their circumstances are not analogous. However, where removal is not possible this argument cannot be sustained, as Johnston argues: "[t]he situations are only distinguishable where the immigrant is detained solely for the purpose of deportation. Outside these circumstances the situations are entirely analogous. The immigrant is detained because he poses a risk to the public, the British citizen is not. ${ }^{" 67}$ In $A v$ Secretary of State for the Home Department the Secretary of State sought to distinguish the case of non-citizens who are preventively detained from UK citizens who may pose a threat of terrorism, by arguing that the former were imprisoned in a prison with only three walls, whereas if this regime were to be extended to British citizens, they would be in a prison with four walls. In rejecting this argument, Lord Nicholls commented that

" $[\mathrm{t}]$ heir prison, it is said, has only three walls. But this freedom is more theoretical than real. This is demonstrated by the continuing presence in Belmarsh of most of those detained. They prefer to stay in prison rather than face the prospect of ill treatment in any country willing to admit them."

Similarly, it could be argued that where a detainee prefers to be detained indefinitely rather than accept voluntary repatriation and get out of the so-called three-walled prison, this may also indicate that the choice between freedom and detention is not a real one. Eligibility for the legal protection of refugee status is very restricted, and excludes many people who have bona fide reasons for seeking sanctuary, as MacDonald comments:

"In everyday language, refugees are people seeking asylum in a foreign country because of war, civil war, or other catastrophic events in their own. It is only in the artificial world of the 1951 Convention Relating to the Status of Refugees that a generalised catastrophe disqualifies, rather than qualifies, a person for the status of refugee. It is partly this mismatch between 'legal' or 'Convention' refugees and 'actual' or 'de facto' refugees which has allowed western European governments to enact ever more restrictive measures against refugees, often irresponsibly described as 'bogus' or 'abusive'", 68

However, as we have seen in $R$ (on the application of A) $v$ Secretary of State for the Home Department $^{69}$ the reasons for refusal to accept voluntary repatriation are deemed to be

\footnotetext{
${ }^{67}$ Connor Johnston, 'Indefinite Immigration Detention: Can it be justified?' (2009) 23(4) Journal of Immigration, Asylum and Nationality Law $351,359$.

${ }^{68}$ Ian MacDonald and Ronald Toal, MacDonald's Immigration Law and Practice (7th edn, LexisNexis Butterworths 2008) 12.1.

${ }^{69} R(A)(\mathrm{n} 43)$ paras $56-58$ (Lord Toulson).
} 
irrelevant, when considering the refusal as a factor supporting a finding that a length of detention is reasonable. Therefore, those who would fall into MacDonald's "de facto refugee" category are particularly vulnerable to prolonged and indefinite executive detention in the $\mathrm{UK}$, as their reasons for refusing to accept repatriation are legally irrelevant, but the refusal itself can justify indefinite detention.

The "prison with three walls" argument can be compared to the arguments based on the state's "undeniable sovereign right" to control aliens. Both lines of reasoning allow for a different set of rules to govern the state's powers over non-citizens, and for a lower standard of human rights protection to be applicable in the context of immigration control. Human rights are in theory universal, and protect everyone by virtue of being human - they are not conditional on citizenship. This is reflected in Article 1 of the ECHR, which provides that state parties "shall secure to everyone within their jurisdiction the rights and freedoms defined in Section I of this Convention." However, it seems that in the context of immigration control, states are not required to secure the same standards of the protection of liberty to non-citizens that they would be required to secure for non-citizens outside this context.

\section{Nationality Discrimination, Irrationality and the Principle of Proportionality}

In A v Secretary of State for the Home Department ${ }^{70}$ the majority of the House of Lords found that the regime of indefinite preventive detention of non-citizen terrorism suspects under Part 4 of the Anti-terrorism Crime and Security Act 2001 was incompatible with Articles 5 and 14 of the ECHR because it unlawfully discriminated on grounds of nationality or immigration status. As the impugned provisions applied only to non-citizens, when the threat from international terrorism emanated from British so-called "home-grown" terrorists as well as from non-citizens, they could not be a proportionate means of achieving the legitimate aim of protecting the public from acts of international terrorism. There was no rational connection between the means used and the aim sought to be realised, hence the measures were ineffective as well as discriminatory on the basis of nationality or immigration status.

This landmark case presents an interesting analogy to the situation of non-citizens whose deportation is prevented by practical or legal impediments, but are detained for reasons of public protection under immigration powers. The reasoning of the majority of the House of Lords in A could be applied to such cases of indefinite preventive detention of non-

${ }^{70} A(\mathrm{n} 1)$. 
citizens. However, this jurisprudence has yet to be extended to cases of preventive detention under immigration powers outside the counter-terrorism context. Therefore the finding that indefinite detention of non-citizens without charge was, inter alia, a breach of Article 14 of the ECHR, the subsequent release of the applicants, and the adoption of a control order regime has created a paradoxical situation in which two groups which are similarly situated are treated differently: those who are suspected of terrorism cannot be detained whereas those who are thought to present a lower, and even a very low, risk to the public are subjected to indefinite detention.

The effect of law and policy in the areas of immigration, asylum, and terrorism has therefore been that preventive detention of those who are considered to pose the greatest risk to the public and to national security is prohibited, whilst those non-citizens who pose even a small risk of non-terrorism related crime can be detained indefinitely on preventive grounds. The reasoning of the House of Lords regarding discrimination on the basis of nationality or immigration status can also be applied to the latter group, as British nationals who have finished their sentence but are at risk of reoffending cannot be detained, and there is no rational basis for this, given that the same threat to public safety can be presented by both groups. $^{71}$

The ECtHR's doctrine of proportionality requires that any measure or action restricting rights under the ECHR to pursue a legitimate aim be suitable to achieve the legitimate aim and be necessary to achieve that aim. Finally, the restriction of the right must be proportionate to the aim pursued, being the least restrictive means of achieving the legitimate aim. ${ }^{72}$ The final stage of this test involves examining whether the measure or action strikes a proper balance between the aim pursued and the individual's rights. The indefinite detention of non-citizens who cannot be deported on grounds of public protection is not proportionate in that it is not an appropriate means of pursuing the legitimate aim of protecting the public, it is not the least restrictive means and does not have a rational connection with the legitimate aim because the threat of crime does not come exclusively, or even mainly from non-citizens. ${ }^{73}$ Finnis argues that the reasoning of the majority in $A v$ Secretary of State for the Home Department was flawed as it was based on a mistaken interpretation of the Hardial Singh and Chahal principles. ${ }^{74}$ An intention to deport the

\footnotetext{
${ }^{71} A$ (n 1) para 183 (Lord Rodger).

${ }^{72}$ See, for example, the judgement of the Grand Chamber of the ECtHR in Janowski v Poland (Application no. 25716/94).

${ }^{73}$ A (n 1), para 44 (Lord Bingham), para 189 (Lord Rodger), para 236 (Baroness Hale).

${ }^{74}$ John Finnis, 'Nationality, Alienage and Constitutional Principle' (2007) 123 LQR 417, 438.
} 
detainee was sufficient to satisfy the requirements of Hardial Singh and Chahal that deportation proceedings are conducted with due diligence, even where there is no real possibility of deporting the detainee in the foreseeable future, because circumstances can change and barriers to deportation may be overcome or disappear in the future. As long as the Secretary of State is keeping the possibility of deportation under review, Finnis argues that this is sufficient to meet the condition that action is being taken with a view to deportation.

In the case of $A$, ministers had been seeking diplomatic assurances from the Governments of the applicants' countries of origin that they would not be subjected to ill treatment if returned. Finnis considers that the seeking of diplomatic assurances constituted action with a view to deportation and was being taken, as this could remove the risk that they would be subjected to inhuman treatment or torture. His finding that such diplomatic assurances and memoranda of understanding would be capable of removing the risk makes no mention of the findings of the UN Human Rights Committee and the UN Committee Against Torture, that memoranda of understanding were not capable of removing the risk of ill treatment in the cases of Alzery $v$ Sweden ${ }^{75}$ and Agiza $v$ Sweden ${ }^{76}$ respectively, but is based on the findings of the Special Immigration Appeals Commission in Abu Qatada v Secretary of State for the Home Department ${ }^{77}$ and $D D v$ Secretary of State for the Home Department. ${ }^{78}$ Indeed, the House of Lords has since expressed doubts as to the effectiveness of such diplomatic assurances. ${ }^{79}$ According to Finnis, the impugned measures in the case of the Belmarsh detainees did not discriminate on the basis of nationality, because the detainees were wrongly assumed to be in the same position as British citizens who cannot be deported, when in fact they may be able to be deported at some future time. Finnis accepts that the detainees in Av Secretary of State for the Home Department were in the same position as other immigration detainees against whom deportation proceedings are being taken, but he believes that in most deportation cases indefinite detention can be justified on the grounds that action is being taken with a view to deportation, notwithstanding that deportation may not currently be possible.

\footnotetext{
${ }^{75}$ Alzery v Sweden (2006) 14 IHRR 341 (Human Rights Committee) 25 October 2006.

${ }^{76}$ Agiza v Sweden (2005) 12 IHRR 958 (Committee Against Torture) 20 May 2005.

${ }^{77}$ Abu Qatada v Secretary of State for the Home Department [2007] UKSIAC 15/2005 (SIAC) 26 February 2007.

${ }^{78}$ DD $v$ Secretary of State for the Home Department, Appeal No: SC/42 and 50/2005 (SIAC) 27 April 2007.

${ }^{79}$ RB (Algeria) v Secretary of State for the Home Department [2008] EWCA Civ 290 (CA) 115, (Lord Phillips).
} 


\section{ANALYSIS}

\section{Security, Risk and "Pre-crime"}

In recent years, there has been a paradigmatic shift within criminology in which a securitybased analysis of crime has become predominant - this has led to changes in criminal justice policy. Zedner sees the foundations of this change in the rational choice theory of economics and observes that this field of economics is having increasing influence within sociology. ${ }^{80}$ Under this security-based analysis, crime is a rational choice - the product of a cost-benefit calculation - and is therefore morally neutral. This view, Zedner comments, is popular not only because it explains the failure of the deviancy criminological model but also because in emphasising agency and the freedom of the individual it is consistent with the dominant political philosophy of neo-liberalism.

This view has far-reaching implications for criminal justice policy, displacing the traditional justifications for punishment and undermining the basis of the system of post-hoc justice which has been constructed over centuries. Retribution and rehabilitation are no longer convincing reasons for punishment, because crime is no longer seen as immoral but instead as a morally neutral rational choice. As Zedner points out, under a security-based analysis even deterrence no longer appears to be a credible justification for punishment, given that for some socially excluded and disadvantaged populations the unlikely prospect of imprisonment provides little disincentive to committing crime, because they have very little to lose ${ }^{81}$ It could be argued that this is particularly true for irregular migrants, as they are not permitted to access employment or public funds, and are often subjected to particular controls such as reporting and residence requirements. Indeed, whilst in detention they may actually have greater access to 'goods' such as employment opportunities, education and training, and healthcare services, than they would if they were not detained. ${ }^{82}$

\footnotetext{
${ }^{80}$ Lucia Zedner, Criminal Justice (OUP 2004) 285.

81 ibid, 292.

${ }^{82}$ Paid work opportunities, education and healthcare facilities are available in immigration removal centres as well as in prisons. For example see

<https://www.gov.uk/government/uploads/system/uploads/attachment_data/file/257748/paid-work.pdf> accessed 30 May 2014. At Harmondsworth Immigration Removal Centre, for example, in addition to paid work for detainees (albeit at low rates of pay given that this work is exempted from the minimum wage legislation), there are adult education facilities, and 24 hour medical care, <http://www.geogroup.co.uk/harmondsworth-irc> accessed 30 May 2014, whereas outside of immigration removal centres asylum seekers do not meet the requirements of the "ordinary resident test" that confers an automatic right to free hospital treatment or exemption from charges for hospital treatment after one year of residence in the UK, following the Court of Appeal judgment in $R(A) v$ Secretary of State for Health [2009] EWCA Civ 225. Asylum seekers, visa overstayers, and irregular migrants have no right to work in the UK, if they are successful in applying for a work permit their right to work is restricted to the very restrictive list of occupations listed in the shortage occupation list.

<https://www.gov.uk/government/uploads/system/uploads/attachment_data/file/308513/shortageoccupationlista
} 


\section{Protecting the Public? Challenging the Indefinite Preventive Detention of Non- Citizens}

The term "pre-crime" was coined by Philip K. Dick in his 1956 science-fiction short story "Minority Report", ${ }^{83}$ in which he writes of a society which has eradicated crime by predicting crimes through the use of "precogs" - humans who have precognition ability - and then detaining the prospective offenders before the crimes are committed. The reorientation of the criminal justice system from a retrospective system, which investigates, tries, and punishes, to a prospective system of anticipating crime, assessing risk, and reducing opportunities for offending is a logical consequence of the adoption of the security-based analysis of crime. If crime is a rational choice, the state can only hope to reduce it by intervening before an offence is even conceived, reducing temptation, and increasing the costs to be entered into the cost-benefit analysis. Increasing the severity of punishment will only deter those who are the most risk-averse, given the low chances of being caught. Therefore, the state should engage in profiling of risky populations, and target them with surveillance and other control measures, with the intention that the profiled group will commit less crime because they have been made aware of their profile and the concomitant increase in the likelihood of detection. ${ }^{84}$

From the amoral standpoint of security analysis, taking pre-emptive measures is straightforward. However, if one steps away from this view, several distinct but interconnected difficulties with this approach become apparent. First, there is a danger that identifying populations which pose a higher risk of committing crime the state further stigmatises the most disadvantaged groups in society, as these are the groups which are more likely to make a rational choice to commit crime, given that they have the least to lose.

Furthermore, as disincentives are less effective on those with the least to lose, preemptive incapacitation becomes the most attractive method of dealing with such groups. Secondly, the act of profiling the most disadvantaged has an inherent risk of entrenching social exclusion and deprivation, which in turn may increase the perceived risk, leading to a perpetual ratcheting up of pre-emptive coercive measures against the targeted groups. Thirdly, the act of profiling can be politicised, with popular demands for unpopular minorities to be profiled and subjected to ever-more stringent controls. Indeed, the ancillary effects of profiling of the targeted groups may increase their risk because their labelling as a high-risk group leads to their further social exclusion and embedding of their pariah status,

pril14.pdf > accessed 30 May 2014, and they have no recourse to public funds, including local authority housing. For a (non-exhaustive) list of the benefits included in the definition of "public funds" see <https://www.gov.uk/government/publications/public-funds--2> accessed 30 May 2014.

${ }^{83}$ Philip K Dick, Minority Report (Gollancz, 2000).

${ }^{84}$ Criminal Justice (n 70) 290. 
leaving them with few options but crime, and almost no disincentives. When an individual is already treated like a criminal, to be convicted of and punished for a criminal offence may be of trivial significance. There is also the intractable problem of the potential for profiling to become a self-fulfilling prophecy in that those who are the subject of increased surveillance and other pre-emptive actions will almost inevitably become the groups with the highest crime rates, because of the increase in detection amongst this group vis-à-vis the general population. ${ }^{85}$ As McCulloch and Pickering argue, "[p]re-crime laws and the coercive measures that travel with them mobilize prejudice around identity and lead to intensified politicization of policing and law." ${ }^{86}$ Although McCulloch and Pickering's arguments are framed within the counter-terrorism context, their observations on pre-crime are pertinent to the wider pre-crime agenda:

"Counter-terrorism and the pre-crime framework it animates formalizes the selffulfilling prophesy of selective law enforcement by embedding pre-emption into formal law, increasing police powers and increasing the intensity and duration of coercion linked to police discretion and action." ${ }^{, 87}$

Increasing the coercive powers of the state has also been taking place outside the counter-terrorism context, with pre-emptive coercive measures being used within the immigration control context; using immigration powers to achieve a pre-emptive solution to crime control in the policing of non-citizens. The security paradigm is consistent with a utilitarian view of criminal justice in that it prioritises the benefit to wider society over the rights of the individual to be free from the coercive powers of the state if they have not committed a criminal offence, as Zedner observes:

"although security, in the objective sense of protection from threat, is posed as a universal good, it is predicated upon that which threatens and its pursuit entails the identification, targeting, and exclusion of those deemed to threaten (Crawford, 1998b). The consequent potential for social exclusion is exacerbated by the common tendency, both individual and collective, to overstate exposure to risk and hence to

\footnotetext{
${ }^{85}$ An example of this is the disproportionately large number of black men in prisons in England and Wales and their disproportionate representation in stop and search figures. The Equality and Human Rights Commission reported in How fair is Britain? Equality, Human Rights and Good Relations in 2010 The First Triennial Review, (2010) that black people are, on average, five times more likely to be imprisoned than white people in England and Wales. Equality and Human Rights Commission, Stop and think - A critical review of the use of stop and search powers in England and Wales (2010) found that black people were at least six times more likely to be stopped and searched than white people.

${ }^{86} \mathrm{Jude}$ McCulloch and Sharon Pickering, 'Pre-crime and Counter-Terrorism - Imagining Future Crime in the "War on Terror"” (2009) 49 British Journal of Criminology 628, 635.

87 ibid, 637-638.
} 


\section{Protecting the Public? Challenging the Indefinite Preventive Detention of Non- Citizens}

demand ever greater protections. ... a fundamental presumption of classical penal theory is that those who do not violate the criminal law have the rightful expectation of enjoying their liberty without interference." 88

The benefit of security for the majority is held out as trumping the rights of the minority groups that are likely to find themselves targeted by the state in its pursuit of security. In this way, a construction of the majority and minority is created, setting "us" - law abiding, upstanding, and familiar apart from "them" - the suspect, dangerous, other. ${ }^{89}$ Like utilitarianism, the security paradigm is also vulnerable to the tyranny of the majority criticism. It is perhaps ironic that the epithet "security" is also used by classical liberalism to denote security of the individual from the arbitrary use of the coercive powers of the state.

\section{Territorial State Sovereignty}

International human rights law is founded on the principle that human rights are universal; and in becoming a party to human rights instruments with enforcement mechanisms, such as the ECHR, or the International Covenant on Civil and Political Rights (ICCPR) ${ }^{90}$ a state appears to be voluntarily accepting certain limitations on its sovereignty. However, throughout the case law, both in the UK's domestic courts and at Strasbourg, there is a theme of the concept of territorial sovereignty side-lining human rights obligations in the context of immigration control. In this sphere, a lower standard of human rights protection appears to be permissible, and the state's "undeniable sovereign right to control aliens' entry into and residence in their territory" 91 allows treatment of non-citizens which would not be permitted in relation to citizens without being characterised as being discriminatory. The alien does not have a right to reside in the territory of the state, and although the ECHR may provide him with a right not to be removed, his remaining in the state can entail some unpleasant consequences for him, from which human rights norms appear to offer little protection. When

\footnotetext{
${ }^{88}$ Lucia Zedner 'Too Much Security' (2003) 31 International Journal of the Sociology of Law 155, 166, NB the Crawford 1998b reference refers to A Crawford, 'Community safety and the quest for security: holding back the dynamics of social exclusion’ (1998) 19 Policy Studies (3/4), 237.

${ }^{89}$ There are some parallels to be found here with Bentham's contention that where the perpetrator cannot be punished, punishing an innocent person for a crime that has been committed is justified by the benefit to the wider community of doing so. As measures taken in the pursuit of security have the potential to make the majority feel more secure or at least that action is being taken to decrease the threat of crime, the detriments suffered by the minorities who are targeted by the measures are outweighed in the felicific calculus. See Jeremy Bentham, 'Principles of Penal Law' in John Bowring (ed), The Works of Jeremy Bentham (Russell \& Russell Inc., New York 1962).

${ }^{90}$ It should be noted that the Human Rights Committee, the supervisor of state parties' obligations under the ICCPR, only has competency to receive individual petition if the state party has ratified the First Optional Protocol to the ICCPR, which recognises the right of individual petition.

${ }^{91}$ Saadi v United Kingdom (n 60) para 64.
} 
comparing this area of state activity to other areas impacted by human rights norms, this seems strange. At this stage of the development of human rights jurisprudence, it would be difficult to imagine a state arguing a defence of sovereignty in other human rights cases, an argument which in theory could be attempted in relation to any human rights issue. The state, in becoming a party to the human rights instrument, has agreed to bind itself in a manner which, it could be argued, is a curtailment of its sovereignty but the consent to be bound can itself, as an expression of the will of the democratic polity, be seen as an indication that this is consistent with the sovereignty of the state. ${ }^{92}$

The concept of state sovereignty is intimately bound up with territoriality and the idea of the nation state, defining itself through, inter alia, the power to exclude and include, and a monopoly on the legitimate use of violence. ${ }^{93}$ Cornelisse tracks the development of the concept of territorial sovereignty from Medieval Europe to the present day, finding that the process of establishing an independent territorial state system, which began with the Peace of Westphalia, coincided with the development of the concept of a sovereign body politic uniting the ruler and the ruled, and that the two concepts fused to create the modern sovereign nation state. Rousseau's conception of popular sovereignty, which according to Cornelisse "cannot be outdone", accepts the absolutist nature of sovereignty which Hobbes' theory entailed, but the absolute power is vested in the people, who only exist if they exist within a community:

"The state is the community, but as the people possess exclusive and omnipotent sovereignty that is inalienable, government is merely the executor of the general will of the community."94

Cornelisse argues that, just as the general will of the community was replaced by Hegel with the national will, nationalism shaped the role of the State, which became associated with the nation: "by the end of the nineteenth century, sovereignty, territory and the identity of the political community became inextricably linked." 95

The influence of these philosophers can be seen in the discourse which justifies indefinite immigration detention for the purpose of preventing crime. The Hobbesian social contract comes into existence because people decide to give up their rights to the Sovereign

\footnotetext{
${ }^{92}$ For example, see arguments raised in Ryan Goodman, 'Human Rights Treaties, Invalid Reservations, and State Consent' (2002) 96 The American Journal of International Law 531.

${ }^{93}$ Galina Cornelisse, Immigration Detention and Human Rights: Rethinking Territorial Sovereignty: Volume 19 of Immigration and Asylum Law and Policy in Europe (Martinus Nijhoff 2010) pt 1 ch 2 Limiting Sovereign Power.

94 ibid, 43

${ }^{95}$ ibid, 57.
} 


\section{Protecting the Public? Challenging the Indefinite Preventive Detention of Non- Citizens}

in order to gain protection to remove them from lives that were "nasty, brutish and short." 96 The security-based analysis of crime, which sees crime as a natural, rational choice, can be viewed as a school of criminology that has its roots in Hobbesian philosophy. It can provide a philosophical underpinning for the use of preventive detention measures against non-citizens. A Hobbesian security-based analysis may determine that aliens residing in the territory of the state are not party to the social contract and therefore are liable to experience the coercive powers of the state in order to prevent crime, but are not beneficiaries of the contract, save for the indirect benefit that they may derive from the state's exercise of power establishing law and order.

\section{Slippage of Concepts}

In law, as in other areas of life, people have a tendency to introduce concepts from one area into another and fuse them together, as well as using their separate discourses to influence outcomes in litigation, policy and other decision-making processes. It is well documented that powers introduced under terrorism laws have been used in policing and regulating areas of life that seem to have little to do with terrorism. For example, powers under anti-terrorism legislation have reportedly been used against protestors against the arms trade, ${ }^{97}$ anti-war protestors, ${ }^{98}$ members of the public suspected of trivial offences such as littering or dog fouling, ${ }^{99}$ trainspotters, a student and a pedestrian, ${ }^{100}$ and in one case an 82 year old heckler at the Labour Party Conference in $2005,{ }^{101}$ and to snoop on Council employees suspected of malpractice. ${ }^{102}$ Indeed, terrorism appears to have had a far-reaching impact on immigration

\footnotetext{
96 Thomas Hobbes, Leviathan (Oxford World's Classics 2008) 84.

97 See 'Student Challenges Use of Anti-terror Act', BBC (12 September 2003), <http://news.bbc.co.uk/1/hi/england/london/3101886.stm> accessed 30 May 2014. Powers of stop and search under the Terrorism Act 2000 used against protestors against an exhibition by Defence Systems and Equipment International (DSEi), and at least two arrests made under the 2000 Act.

98 Jamie Wilson, 'Terrorism Act 'used to halt protest', Guardian (16 July 2003) <http://www.guardian.co.uk/politics/2003/jul/16/terrorism.immigrationpolicy> accessed 30 May 2014. See also Article 19, 'The Impact of UK Anti-Terror Laws on Freedom of Expression Submission to ICJ Panel of Eminent Jurists on Terrorism, Counter-Terrorism and Human Rights' (2006), p 6, para 3.2.

99 'Councils to be banned from using anti-terror powers to snoop on people who overfill bins or drop litter', Daily Mail (20 November 2008)

<http://www.dailymail.co.uk/news/article-1087543/Councils-banned-using-anti-terror-powers-snoop-peopleoverfill-bins-drop-litter.html> accessed 30 May 2014.

100 Article 19 (n 90) 3.2.

101 'Labour Issues Apology to Heckler', BBC (28 September 2005) <http://news.bbc.co.uk/1/hi/4291388.stm> accessed 30 May 2014.

102 'Councils snoop on their own staff using anti-terror laws' Telegraph (14 April 2009) <http://www.telegraph.co.uk/news/uknews/5150695/Councils-snoop-on-their-own-staff-using-anti-terrorlaws.html> accessed 30 May 2014.
} 
and asylum policy, with the press, politicians, ${ }^{103}$ and the Home Office ${ }^{104}$ linking terrorism with asylum and immigration, in some cases equating terrorists and asylum seekers. ${ }^{105}$ The United Nations has made reference to asylum seekers and refugees in most of its resolutions on combating terrorism. ${ }^{106}$ Tumlin has analysed the impact of terrorism policy on immigration policy in the US context, and found that immigration powers have been used in terrorism investigations because they offer fewer procedural safeguards than the criminal procedures. $^{107}$

A clear parallel can be seen in the UK's formal linking of criminal law with immigration law under section 23 of the Anti-Terrorism, Crime and Security Act 2001. However, this provision was repealed following the judgment of the House of Lords in $A v$ Secretary of State for the Home Department. ${ }^{108}$ The direct import of immigration law into a criminal law provision regarding executive detention was successfully resisted in $A$, and this may reflect the strong criminal law procedural guarantees inherent in the concept of the rule of law, and perhaps an anxiety that bringing immigration law and its issues of territorial sovereignty into criminal law would result in a general erosion of criminal law due process. This would have a negative impact on the security of the individual citizen, as protections against arbitrary exercise of the State's coercive powers are reduced.

Although similar in its nationality discrimination and consequent irrationality and disproportionality, the use of immigration detention for the purpose of preventive detention has pursued crime control aims through immigration law, rather than criminal law. This has meant that the territorial sovereignty discourse has prevented the logic of the reasoning of the majority in $A$ from being applied in the context of the use of the immigration powers of detention for the purpose of preventing the committing of (general non-terrorism related) crime. The link between immigration law and criminal law is not formalised in the case of preventively detained ex-FNPs, in that criminal law provisions are not used for detention, rather powers of detention, which are corollary to the power to deport, are used to detain. In

\footnotetext{
${ }^{103}$ Anastassia Tsoukala, 'Defining the terrorist threat in the post-September 11 era' in Anastassia Tsoukala and Didier Bigo (eds), Terror, Insecurity and Liberty - Illiberal practices of liberal regimes after 9/11 (Routledge 2008), 66-69.

104 ibid.

105 Roy Greenslade, 'Seeking Scapegoats, the coverage of asylum in the UK press' (2005) Asylum and Migration Working Paper 5 May 2005, IPPR, 28; compare Kundnani, Arun 'The Hate Industry', (Institute of Race Relations, 6 March 2003), <http://www.irr.org.uk/2003/march/ak000003.html> accessed 30 May 2014.

${ }^{106}$ Alice Edwards, and Carla Ferstman, 'Humanising non-citizens: the convergence of human rights and human security' in Alice Edwards, and Carla Ferstman, (eds), Human Security and Non-Citizens (CUP 2010), 19.

${ }^{107}$ Karen C Tumlin, 'Suspect First: How Terrorism Policy Is Reshaping Immigration Policy' (2004) 92 California Law Review 1173, 1198.

${ }^{108} A$ (n 1).
} 


\section{Protecting the Public? Challenging the Indefinite Preventive Detention of Non- Citizens}

this way, the link to the state's "undeniable sovereign right" to control and exclude aliens from its territory serves to legitimise the detention and make it subject to a lower standard of human rights protection. This lower standard is characterised as "proportionality lite" by Cornelisse: in the assessment of whether a measure is suitable to achieve the aim, the ECtHR does not look for a causal link between the immigration detention and its aims but a "close relationship." Cornelisse argues that:

"This logic facilitates the construction of a 'chain' of permitted purposes, which renders the general rule - exceptions to the right to personal liberty must be narrowly interpreted - of little significance when it comes to the use of detention in immigration procedures." 109

It is thus perhaps unsurprising that states have turned to the use of immigration powers to facilitate preventive detention, thereby making it subject to a lower standard of judicial scrutiny. Moekli charts the use of executive detention, arguing that:

"foreign nationals have always been the main target of executive detention powers. While states have often invoked threats of national security to justify the preventive detention of non-nationals, in recent years they have also relied on the far-reaching powers linked to the right to control immigration."

The disapplication of due process norms and human rights in the context of the preventive detention of ex-FNPs finds support from the security-based analysis of crime, and in the utilitarian felicific calculus. The citizen population can feel an increased sense of security because a category of ex-offenders are preventively detained, but because that category is limited to non-citizens, the potential damage to the security of the citizens in the sense of increased anxiety that one is more vulnerable to interference by the state with one's liberty and security, is minimised. This use of preventive detention can also find justification in the security-based analysis of crime as it is premised upon detaining on the basis of a risk analysis, although its confinement to non-citizens is not easily justified by the security-based analysis, as this restriction of the use of preventive detention is not based on risk, since citizens can also present a risk of crime.

McCulloch and Pickering examine the effects of the integration of security and national security into criminal justice, arguing that:

\footnotetext{
${ }^{109}$ Cornelisse (n 93), 298.

${ }^{110}$ Daniel Moekli, 'The Selective "War on Terror": Executive Detention of Non-Nationals and the principle of non-discrimination’ (2005-2006) 31 Brooklyn Journal of International Law 496, 502.
} 
"the move to pre-crime that is taking place embodies not only a trend towards integrating security into criminal justice, but also integrating national security into criminal justice. The shift from post to pre-crime and national security under counterterrorism frameworks encompasses not only a temporal shift, but also a geographic one that involves a blurring of the borders between the states' internal and external coercive capacities." $" 111$

This blurring of the internal and external coercive capacities of the state can cause the further isolation of the irregular migrant, as the states' inherent right in international law to control immigration is emphasised in its exercise of internal coercive capacities against non-citizens.

\section{CONCLUSION}

Theoretically, the power of the Executive to detain the non-citizen is a corollary to the power of the Executive to deport the non-citizen, and must always be used to facilitate deportation. However, barriers to removal can increase the length of detention of a non-citizen, which becomes indefinite preventive detention because a risk of the non-citizen offending is deemed relevant to any decision to detain or release. Considerations of public protection and the risk of the detainee committing crime if released are deemed relevant to the initial decision to detain, the administrative decision whether to release, as well as the judicial determination of bail applications and unlawful detention judicial review actions.

Arguments that administrative preventive detention of non-citizens is not discriminatory are based on what is in many cases a false premise: that the detainee is not in an analogous situation to a UK citizen who poses a risk of offending, because the UK citizen cannot be deported. In cases where there are barriers which render deportation impossible, the administrative detention of the non-citizen in circumstances in which the citizen could not be detained, the facts cannot be distinguished from A v Secretary of State for the Home Department $t^{112}$ and amount to nationality discrimination.

The security-based "pre-crime" analysis is inherent in the justifications of the preventive detention of non-citizens. This can be seen, for example, in $R$ (on the application of I) $v$ Secretary of State for the Home Department, ${ }^{113}$ where Brown LJ accepted that in principle the risk of reoffending could justify detention for an indeterminate period, and that

\footnotetext{
${ }^{111}$ McCulloch and Pickering (n 86) 629.

${ }^{112} A$ (n 1).

${ }^{113} R(I)$ (n 41).
} 


\section{Protecting the Public? Challenging the Indefinite Preventive Detention of Non- Citizens}

if it was possible to predict with "high degree of certainty that, upon release, the detainee would commit murder or mayhem" 114 then this would justify a lengthy period of detention.

Although the modern nation state's fusion of territoriality and sovereignty may have occurred by happenstance, the role of territoriality in linking the state and the nation is key and has emphasised the state's right to exclude and control aliens. Notwithstanding the human rights obligations of the state being voluntarily assumed through its ratification of human rights instruments, the sovereignty of the state is invoked to reduce judicial scrutiny and allow for a lower standard of protection of the liberty of a non-citizen in the context of immigration control.

The administrative preventive detention of non-citizens can be seen as part of a trend to use immigration law to achieve crime control and security aims, as states take advantage of the lower standard of scrutiny that the invoking of territorial sovereignty allows immigration powers to enjoy. Immigration powers have been used in criminal investigations because they offer fewer procedural safeguards compared with criminal law procedures. In $A$ the direct import of immigration law into a criminal law provision was successfully resisted; however, the use of immigration detention powers for the purpose of criminal justice or public protection outside the counter-terrorism context has circumvented the criminal law and its higher standard of review by not formalising a link with criminal law provisions. Although the purported purpose of the detention is to prevent crime, it is authorised under immigration law. The use of immigration law to achieve the purpose of crime control has enabled territorial sovereignty principles to dominate the discourse and prevent the logic of the reasoning in $A$ from being applied to administrative detention of non-citizens in the context of crime control. This is paradoxical because the different treatment which results - between the treatment of irregular migrants who are suspected of terrorist activities and those whom the state contends pose a risk of committing non-terrorist offences - eventuates, notwithstanding that in $A$ Lord Bingham expressly stated that the use of an immigration measure to address a security problem could not be proportionate, both because of its discriminatory effect and because this discriminatory effect undermined its effectiveness. ${ }^{115}$ Both of these reasons are also applicable to the crime control context, yet have not been applied.

\footnotetext{
114 ibid, para 29.

${ }^{115}$ A (n 1), paras 43, 68.
} 
Although its confinement to non-citizens is not easily justified, the preventive detention of non-citizens is supported by the security-based pre-crime agenda, because it is premised upon detainment on the basis of a risk assessment (even if in practice this is often done based on out of date information on the risk that an FNP poses). It also finds justification in the utilitarian felicific calculus. Citizens, the majority group, can feel an increased sense of security because a category of ex-offenders are preventively detained, but because that category is limited to non-citizens, the potential damage to the security of the citizens - in the classical liberal sense of increased anxiety that one is more vulnerable to interference by the state with one's liberty and security - is minimised.

It seems that arguments based on a strong notion of territorial sovereignty often prevent challenges to the indefinite preventive detention of non-citizens; a more realistic interpretation of the importance of the principle of territorial sovereignty would be to view it in the context of the state's international obligations, which the state has voluntarily assumed, and to consider territorial sovereignty considerations alongside other constitutional principles, such as the rule of law and equality before the law. Territorial sovereignty may appear to enable popular punitivism and security-based approaches predicated on pre-emption and discrimination, including indefinite preventive detention of non-citizens by the Executive. Security-based risk analysis approaches to crime control are vulnerable to a number of criticisms, including that they are inevitably discriminatory and entrench disadvantage, and that they lead to the tyranny of the majority. If the lack of suitability is recognised, with preemptive measures that are discriminatory having the inherent risk of not being fit for purpose, then the preventive detention of non-citizens becomes difficult to justify, even according to the lower standard of scrutiny that territorial sovereignty considerations entail, because its efficiency as a preventive crime control strategy can be questioned. The individual citizen is traditionally identified with the state, in the body politic of the ruler and the ruled; the state is often required to enable the will of the majority to prevail, but, in the words of Lady Hale, "the will of the majority cannot prevail if it is inconsistent with the equal rights of minorities." 